Константинова Валентина Валентиновна

студентка

Финансово-экономический институт

ФГАОУ ВПО «Северо-Восточный федеральный университет им. М.К. Аммосова»

г. Якутск, Республика Саха (Якутия)

\title{
РУКОВОДИТЕЛЬ И ПОДЧИНЕННЫЙ
}

Аннотация: данная статья посвящена вопросу отношений руководителя и подчиненных, а также анализу проблемь управления персоналом. В работе представлен ряд рекомендаций для ПАО «Якутскэнерго», направленных на эффективное управление организацией.

Ключевые слова: руководство, руководитель, подчиненный, предприятие, организация, управление персоналом, функции, заместитель, анкетирование.

Актуальность данной статьи заключается в следующем: в современном мире руководство в предприятии является чрезвычайно важной для организации, так как разница между хорошей и отличной фирмой состоит в его управлении, которое осуществляет лицо, направляющее и контролирующее деятельность исполнителей - руководитель.

Постановка проблемы руководителя и подчиненного, является достаточно современным, поскольку во многих структурах создаются трудности в решении проблем управления персоналом. Конфликтные ситуации между руководителем и подчиненным могут перерасти в серьезные конфликты.

Объект исследования: ПАО «Якутскэнерго». Предмет исследования: руководство и персонал компании.

Цель: исследовать отношения руководства и персонала Якутскэнерго.

Руководитель - это должностное положение работающего, который обязан влиять на своих подчиненных таким образом, чтобы они выполняли работу, порученную организацией. 
Результатом усилий руководителя является сгруппированная, направленная и скоординированная работа его подчиненных.

Руководитель является персонифицированным воплощением организации, и к ее целям и проблемам он должен относиться как к своим собственным. но современная научно-техническая революция изменила все условия и характер производственных, хозяйственных и социальных процессов, что руководителю уже сложно одному управлять всем этим. поэтому, он сегодня становиться организатором самостоятельной работы исполнителей, часто объединенных в команды.

В современное время выделяют несколько функций, которые должен выполнять сегодняшний руководитель:

1) стратегическая. заключает постановку целей организации, планирование и разработку стратегий;

2) инновационная. тесно связана с стратегической. для этой функции руководитель создает условия для организационных преобразований, направляет процесс разработки работы и внедрения новых видов продукции и услуг, консультируется с подчиненными;

3) административная:

- контрольная

- организационная

- направляющая

- кадровая

- стимулирующая.

4) коммуникационная. Выполняет налаживание внутренних и внешних связей;

5) социальная. В этой функции руководитель поддерживает благоприятную морально-психическую атмосферу, формирует нормы поведения.

На сегодняшнее время руководителя можно рассматривать в трех ипостасях:

1) профессионал - автор решений, стратегии, планов; 
2) организатор - создатель условий деятельности исполнителей;

3) начальник - предписывает подчиненным необходимые действия, которые они должны в обязательном порядке выполнять [1].

Подчиненные. Все работники организации, кроме руководителя, - его заместители, руководители низшего уровня, рядовые исполнители - являются подчиненными, т.е. лицами, находящимися в подчинении старшего по должности.

Фигура подчиненного характеризуется служебной зависимостью от руководителя, функциональной узостью и односторонностью работы, тесной связью с первичным коллективом, преобладанием межличностных форм отношений при выполнении служебных.

Особую категорию подчиненных составляют сотрудники аппарата руководителя:

1. Помощник. Подбирает информацию необходимую для принятия решений, сортирует и представляет в удобном для ознакомления виде.

2. Консультант. Оценивает качество документов, участвует в выработке решений с правом совещательного голоса.

3. Референт. Знакомится с научной литературой, составляет доклады, рефераты.

4. Заведующий канцелярией. Организует канцелярскую работу, осуществляет техническую подготовку мероприятий, составляет индивидуальные планы работы руководителя.

5. Секретарь. Отбирает устную информацию, отвечает на телефонные звонки, ведет краткую запись сообщений, обрабатывает корреспонденцию [2].

Сейчас мы ознакомимся с объектом исследования краткой характеристикой компании ПАО «Якутскэнерго».

ПАО «Якутскэнерго» - российская энергетическая компания, осуществляет энергоснабжение на территории Республики Саха (Якутия). является основным поставщиком электрической энергии в Республике Саха.

Председатель правления, главный директор - Тарасов Олег Владимирович. 
Отчет составлен по результатам анкет, заполненных работниками ПАО «Якутскэнерго».

Цель анкетирования: оценить параметры руководителя и отношения между руководителем и персоналом.

Гипотеза: показатели параметров у руководителей организации «Якутскэнерго» среди персонала оцениваются отлично.

В крупных и малых организациях отношения между руководителем и подчиненным равны.

Успех руководителя во многом зависит от его умения построить правильные отношения с подчиненными. Доверие к руководителю, признание его авторитета, хороший деловой контакт, близость к людям обеспечивают хороший климат и дисциплину в организации.

Поэтому я провела анкетирование, которое дает возможность оценить параметры руководителя глазами подчиненных такие как компетентность руководителя, эмоциональность, требовательность.

Опрос проводился среди персонала ПАО «Якутскэнерго», в коллективе оперативно-диспетчерской службы. Тест состоял из 21 вопроса, с каждым из которых испытуемый мог согласиться или нет.

На большинство вопросов работники ответили утвердительно. Отрицательно ответили на 6 вопросов. каждый вопрос оценивал определенный параметр руководителя.

Из анкетирования я выявила, что в глазах подчиненных компетентность у руководителя оценивается средне, эмоциональность более-менее нормально, т.е. он иногда интересуется жизнью своих сотрудников и пытается понять и войти в их положение, и третье качество, требовательность и справедливость, его умение взаимодействовать с подчиненными, работники оценили высшей оценкой.

Из этого следует вывод, что в крупных компаниях, как ПАО «Якутскэнерго», отношения между руководителем и починенным более формальное и 
натянуто рабочее, чем в обычных малых организациях. Руководитель и подчиненный встречаются только на рабочем месте и, следовательно, у них чисто рабочие отношения. руководители в крупных компаниях нацелены лишь на достижение целей организации и требуют от своих подчиненных только выполнение своих обязанностей по работе. Поэтому они более строги и требовательны к своему персоналу. Руководители мало интересуются личной жизнью работников, личных предпочтений среди своих подчиненных руководитель не имеет.

Исходя из анкетирования, предлагаются такие рекомендации:

1. Руководитель должен улучшить свою компетентность и профессиональное мастерство, показать его своему персоналу.

2. Улучшить эффективность руководства над персоналом в целом у этой организации с руководством все нормально, т.к. это крупная организация и то, что руководители в нем более строги к своему персоналу, чем в других малых группах правильно. потому, что в крупной организации условия не такие как в малых и чисто деловой стиль общения между руководителем и подчиненным наиболее уместно, чем другие какие-либо стили управления.

В нашей работе мы рассмотрели основные понятия руководителя и подчиненного, проблему отношений между руководителем и подчиненным. Выяснили, что в крупных компаниях отношения между руководством и коллективом бывают чисто формальные и рабочие.

Выявили ряд рекомендаций для организации ПАО «Якутскэнерго», мы уверены, что они помогут руководителям этой организации найти свои ошибки в управлении, исправить их и усовершенствовать свой метод руководства.

\section{Список литературы}

1. Основы менеджмента: Учебник / В.Р. Веснин. - М.: Проспект, 2013. C. 108 .

2. Практический менеджмент персонала: Пособие по кадровой работе. - М.: Юристь, 2011. - 496 с. 
3. Борисова У.С. Проблема оттока молодых специалистов в организации (на примере ОАО АК «Якутскэнерго» Якутская теплоцентраль) / У.С. Борисова, Ю.А. Опарина // Экономика и социум. - 2013. - №3 (8). - С. 501-503. 